\title{
Stepped Solar Stills' Development and Improvement for Seawater Desalination
}

\author{
Ahmed N. Shmroukh ${ }^{1,2}$, Shinichi Ookawara ${ }^{2}$
}

\begin{abstract}
Nowadays freshwater needs were covered by fossil fuel-based desalination systems in many areas over the world. However, fossil fuels' excessive burning results in rapid depletion and pollution of the local environment as well as threat to life sustainability. Therefore, through the last few decades the scientific community focused on the systems relying on solar energy in seawater desalination as a clean alternative. Stepped solar stills, which convert solar energy to the required heat for producing freshwater in seawater desalination, are paid much attention. This article provides a comprehensive analysis of stepped solar stills' development. Performance enhancement techniques, desalinated water production, efficiency and maximum theatrical production are discussed. This work aims to keep researchers and concerned scientific community abreast of stepped solar stills' improvements. Such stills of low construction and running costs can meet the freshwater daily needs for small communities in coastal areas, islands and rural areas especially in Mideast. In conclusion, this review clarified that the stepped type solar stills still need multiple improvements to enhance their production efficiency and freshwater quantity. Further attention should be paid to the design of modified stills to attain better and efficient solar heat absorption as well as evaporation of seawater.
\end{abstract}

Keywords: Freshwater production; Development Mechanisms; Productivity enhancement; Stepped solar still.

\footnotetext{
Received: 19 July 2021/ Accepted: 5 September 2021

$\square$ Ahmed N. Shmroukh, ahmed.shmroukh@eng.svu.edu.eg Shinichi Ookawara, ookawara.s.aa@m.titech.ac.jp

1. Department of Mechanical Engineering, Faculty of Engineering, South Valley University, Qena 83521, Egypt

2. Department of Chemical Engineering, Graduate School of

Science and Engineering, Tokyo Institute of Technology, 2-12-1

S1-26, O-okayama, Meguro-ku, Tokyo 152-8552, Japan
}

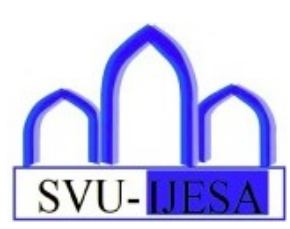

1 Introduction

Freshwater plays a vital role in daily life activities and its need is continuously increasing. Nowadays water scarcity in many regions all over the world is undoubted fact, as indicated in the recent century water scarcity map [1] shown in Figure 1, the most water shortage suffering region is the Middle East where also suffers high water stress or consumption needs. On the other hand, this region contains available seawater areas [2,3] such as Red Sea, Mediterranean Sea, Dead Sea and Arab Golf which are suitable sources for freshwater production using desalination techniques.

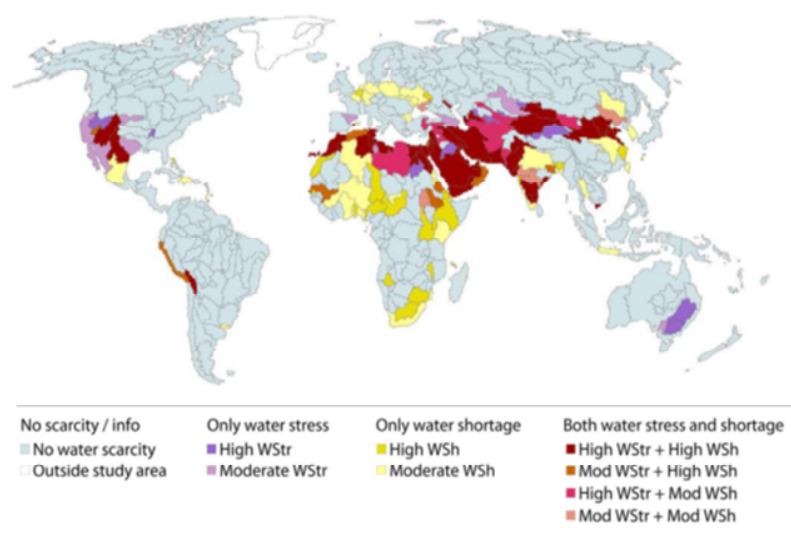

Fig. 1 Water scarcity map [1].

However, as a bright side this specific region has very high incident solar radiation intensity as indicated in global solar radiation map [4] of Figure 2, moreover, this region has relatively high sunshine duration compared with other countries all over the world $[4,5]$. Therefore, it is recommended to use solar energy in seawater desalination techniques for producing freshwater in such region, due to the availability of seawater and solar radiation and regarding the continues fossil fuel increasing costs. 


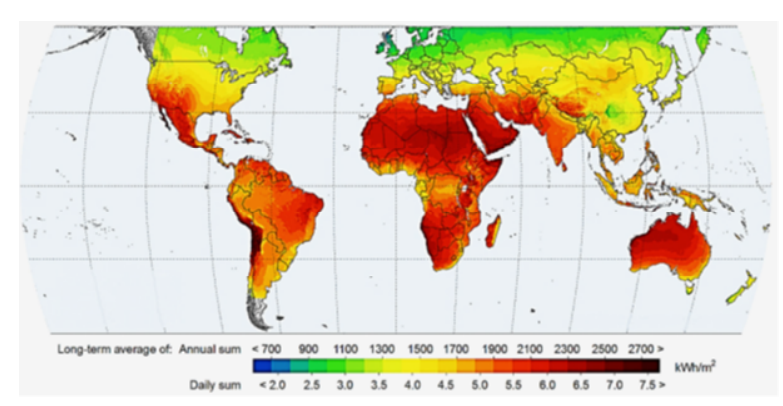

Fig.2 Global irradiation map [4].

Solar energy based desalination systems become important to be used in rural and remote areas like Middle East as potable water reliable source, due to their low cost and uncomplicated infrastructure without electricity grid connection. While, different solar energy utilization systems can be used in such areas such as evacuated tubes, flat plat collectors, central receivers and solar stills which convert the solar energy to be the main driving thermal energy for thermal desalination processes. However, this work will focus on solar still systems specially the stepped type. Furthermore, this article contains different sections such as a section based on discussing stepped solar stills' principal of operation, another one mainly based on highlighting the research studies that have been done to enhance the stepped solar stills performance which available in open literature, and finally a concluding remarks section summarizing the main gained points from this study.

\section{Work Theory of Stepped Solar Stills}

For many times, efforts were made to obtain potable water from saline water and seawater desalination using solar energy. While, solar stills were developed as the earliest solar energy based desalination technologies. Therefore, the demand for developing enhanced solar still based desalination technology was increased.

Solar stills are one of the simplest and cheapest seawater desalination techniques, specially stepped structure. A stepped type solar still composes of a high solar absorptive dark colored step wise basin instead of flat one as shown in Figure 3, transparent material cover allowing incident radiation to pass into the seawater in the steps and works as condensing surface for the evaporated water, outer insulated structure to prevent the generated thermal energy from scape outward and a collection trough guiding the condensed freshwater to the collection tank.

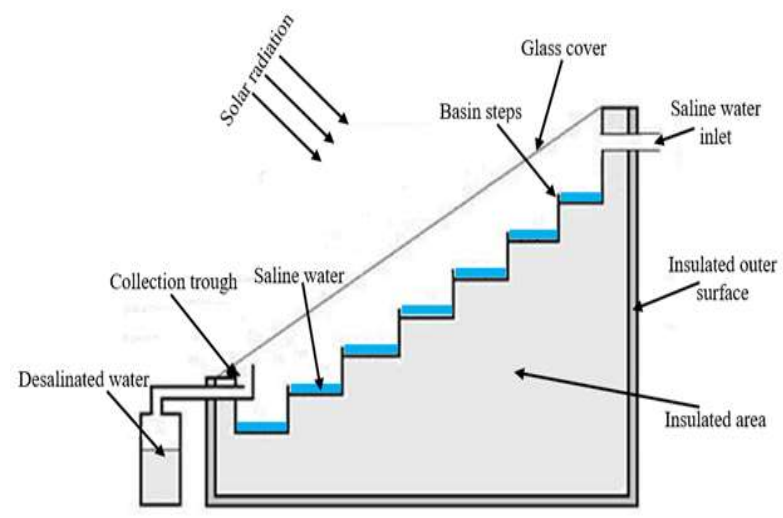

Fig.3 Simple stepped solar still structure.

Stepped solar stills mainly could be divided into passive and active stills, which depending on water circulation existence in the system. Passive stepped stills have many advantages such as there is no need for electrical pumping power, they are easy to operate and simple in design. On the other hand, their main drawback is that due to the latent heat of condensation loss through the transparent cover they have low freshwater production compared with active stepped solar stills. Such low productivity influenced their daily production efficiency which generally can be given by [6]:

$$
\eta_{d}=\frac{\sum m_{w} h_{f g}}{\sum A I_{(t)}}
$$

Subsequently, using stepped solar desalination technology become an important solution for potable water shortage problems in hot arid areas such as Middle East, while such technology is inexpensive with low maintenance costs and less environmental impact compared with reverse osmosis technology (RO).

\section{Enhancement Techniques and Developmental Trends}

3.1 Simple stepped stills under different environmental and operating conditions

Both passive and active basic shape stepped solar stills tested under different conditions were discussed through this section. 


\subsubsection{Passive simple stepped stills}

Kabeel et al. [7] studied theoretically and experimentally a wick supported stepped solar still equipped with solar collector for inlet seawater preheating installed in Kafrelsheikh, Egypt. Their modified system shown in Figure 4 composed of conventional solar still to compare with their modified stepped solar still, both were single basin type with the same total area. The stepped still trays were supported with wicks on their vertical side, to increase the seawater evaporation areas that exposed to solar radiation. Moreover, a seawater solar preheater was installed before their stepped still allowing the inlet seawater to become hot seawater increasing the stepped still productivity. They verified the experimental data with the developed theoretical model results and a good agreement was obtained. Their outcomes derived that, as the water depth decreased as the stepped solar still productivity increased. Moreover, the step tray width and depth had strong effect on the stepped still daily efficiency, with $120 \mathrm{~mm}$ tray width and $5 \mathrm{~mm}$ tray depth the stepped still gave its maximum daily productivity higher than that for the conventional one by approximately $57.3 \%$. Furthermore, the daily efficiency of both stepped and conventional stills were reached about $53 \%$ and $33.5 \%$, respectively. The wicks increased the stepped still productivity by up to $5 \%$. While, feed seawater preheating decreased the modified system efficiency to the half and improved the productivity slightly. However, their maximum obtained daily productivity reached $6.0801 / \mathrm{m}^{2} /$ day at an efficiency of $66.6 \%$, while, the calculated maximum theoretical productivity of their system was 9.129 $1 / \mathrm{m}^{2} /$ day.

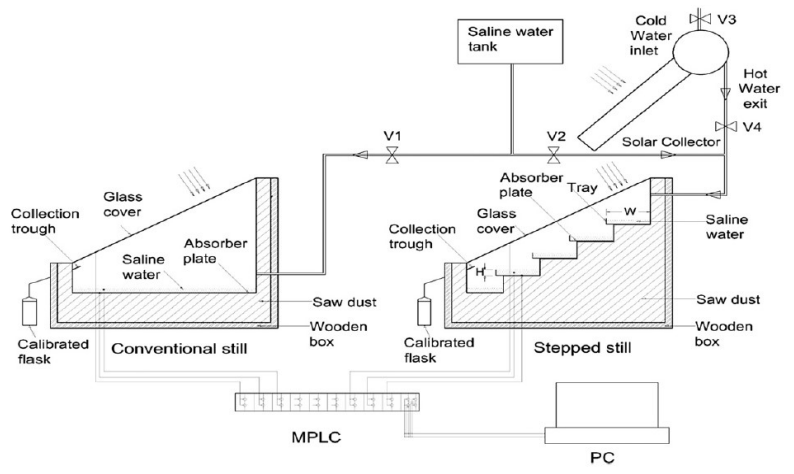

Fig.4 Passive modified stepped still of [7].

Velmurugan et al. [8] evaluated the performance of stepped solar desalination still equipped with mini solar pond, this have been done to preheat the feed water installed in Madurai, India. The proposed combined setup shown in Figure 5, was mainly consisted of settling tank for clarifying the feed industrial effluent and it was equipped with pebbles, coal and sand layers, respectively, then a mini solar pond received the clarified effluent to be preheated to flow to the stepped still, finally, a conventional still was connected to the setup and equipped with different additives to enhance the productivity such as pebble, wicks, baffle plate, sponges and fins with comparing the setup performance for each modification. Each 1-hour Velmurugan et al. [8] were measured saline water, basins and glass covers temperatures and the condensation rate of both solar stills. Also, they measured ambient temperature, wind velocity and solar intensity. They obtained a maximum productivity of $80 \%$ in case of adding fins and sponges in the solar still, while, the daily desalinated water production was reached up to $6.1201 / \mathrm{m}^{2} /$ day at an efficiency of $59.0 \%$, and for the calculated maximum theoretical productivity the value reached about 10.368 $1 / \mathrm{m}^{2} /$ day.

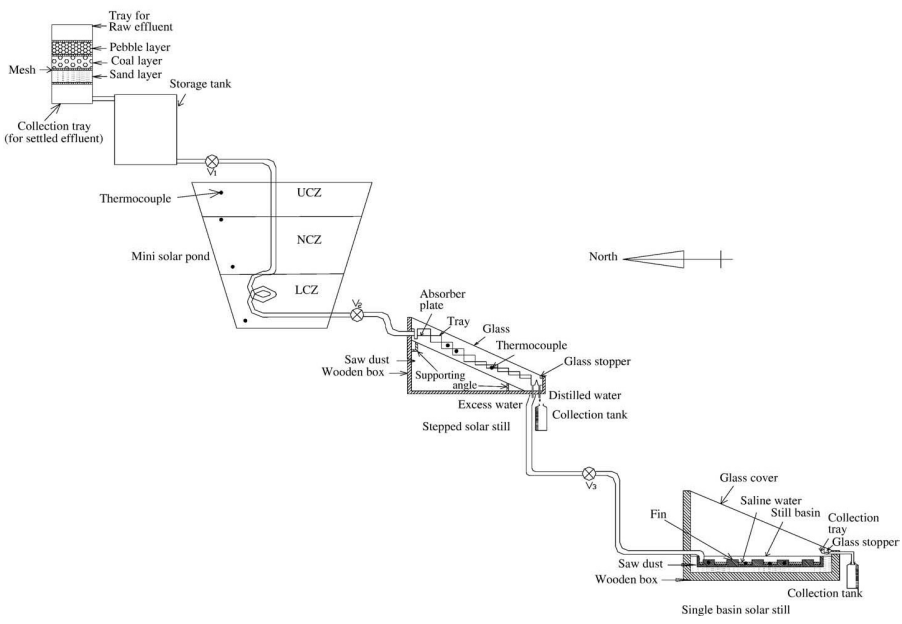

Fig.5 Passive combined system of [8].

Pillai et al. [9] studied experimentally a stepped solar still performance under unsealed and sealed conditions in Bangalore, India. The designed basin with water channels was comprised of welded semicircular pipes fixed at constant slop to act as connected steps, moreover, sealing feed water with the airtight cap which left open for unsealed condition experiment. They found that, their proposed new stepped still design was produced a daily production of approximately 3.700 $1 / \mathrm{m}^{2} /$ day while, the calculated maximum theoretical productivity was $6.4001 / \mathrm{m}^{2} /$ day. Furthermore, Gawande and Bhuyar [10] examined the performance of simple 
shape stepped desalination still under different climatic conditions in Buldana, India. The saline water was followed to the basin steps one by one, as the step was filled with water it spilled the excess amount to the next step as shown in the following Figure 6. They concluded that, there was an increase in productivity in case of wind speed increase, this happened due to the increase in glass cover to ambient air convective heat transfer coefficient which lead to an increase in glass cover and water surface temperature difference. Also, they concluded that, the maximum obtained daily productivity reached $1.2001 / \mathrm{m}^{2} /$ day at an efficiency of $28.5 \%$ at a wind speed of $1.45 \mathrm{~m} / \mathrm{s}$, while, the calculated maximum theoretical productivity of their system was $4.2101 / \mathrm{m}^{2} /$ day.

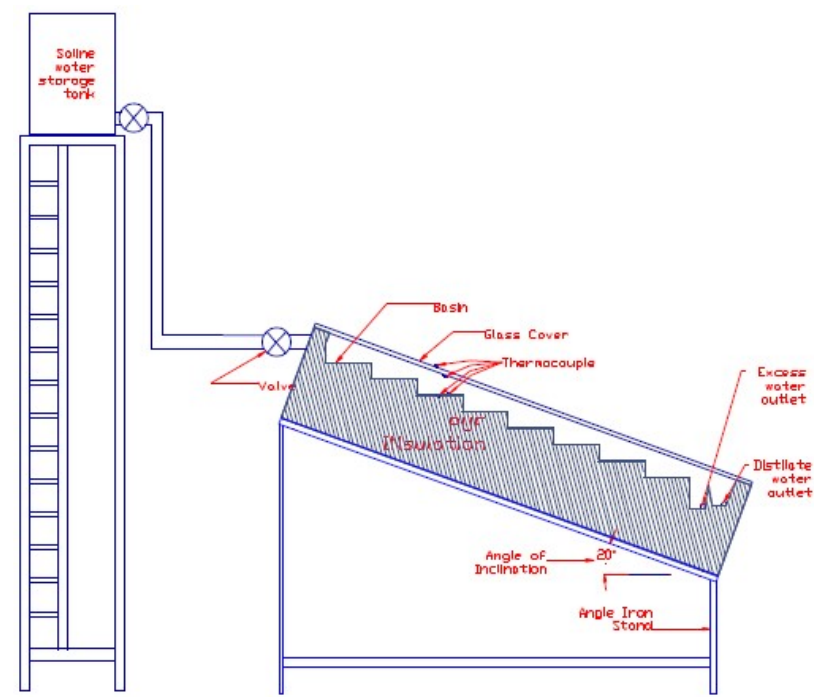

Fig.6 Passive simple shape stepped solar still proposed by $[10]$.

Moreover, at the same place of Buldana, India, Gawande et al. [11] tested the performance of the same simple shape stepped still of [10] under different saline water depth of $5 \mathrm{~mm}, 7.5 \mathrm{~mm}$ and $10 \mathrm{~mm}$. Conducting a comparison on the three depths they observed that, as the saline water depth decreased as the production increased, whereas the daily production was reached up to $0.745 \mathrm{l} / \mathrm{m}^{2} /$ day, $0.910 \mathrm{l} / \mathrm{m}^{2} /$ day and $1.440 \mathrm{l} / \mathrm{m}^{2} /$ day for $10,7.5$ and $5 \mathrm{~mm}$ seawater depth, respectively, they also performed an economic analysis on their system and found that, the payback period of the proposed stepped still reached about 1064 days, 958 days and 823 days only for $10,7.5$ and $5 \mathrm{~mm}$ seawater depth, respectively. While, the calculated maximum theoretical productivity of their system was about $4.198 \mathrm{l} / \mathrm{m}^{2} /$ day. Another simple shape stepped solar still was tested in Khulna,
Bangladesh by Islam et al. [12], they constructed a conventional solar still to compare its performance with the stepped type one, their system of Figure 7 was consisted of four rectangular tray steps of $0.13 \mathrm{~m}$ width and $0.9 \mathrm{~m}$ length with $0.05 \mathrm{~m}$ height in dimension. In heat and mass transfer analysis they assumed that the humid air in the still didn't absorb solar radiation and the evaporated water didn't leak from the still. Based on their results it could be inferred that, the freshwater production of their design could reach up to 3.970 $1 / \mathrm{m}^{2} /$ day and the calculated maximum theoretical productivity was about $9.469 \mathrm{l} / \mathrm{m}^{2} /$ day.

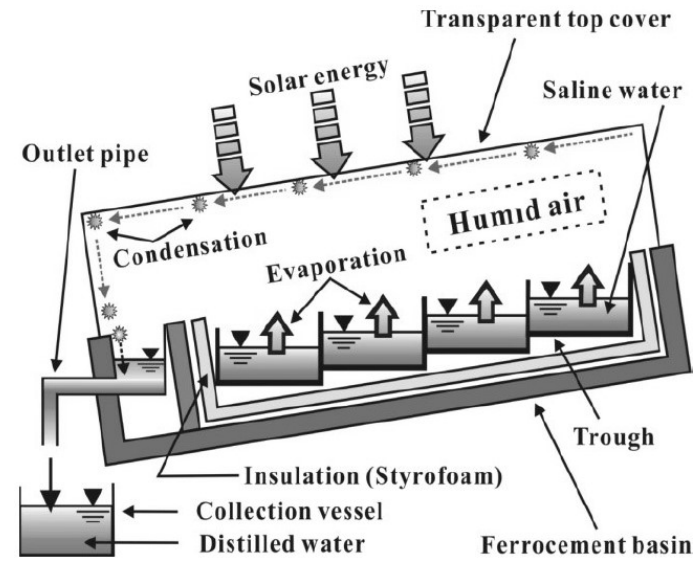

Fig.7 Passive stepped solar still proposed by [12].

\subsubsection{Active simple stepped stills}

For active stepped solar still with basic shape A. S. Abdullah [13] improved the performance of simple stepped still equipped with solar air heater to preheat the feed seawater before entering the solar still installed in Tanta, Egypt, and comparing its performance with a conventional solar still. As shown in Figure 8, the developed setup composed of seawater main tank which provided both stepped and conventional still with the same amount of feed seawater, conventional single basin solar still for comparison with the nearby simple shape stepped still which was connected directly with solar air heater, while the heater was consisted of black polyethylene flexible cylinder with a diameter of $0.50 \mathrm{~m}$ and a length of $20 \mathrm{~m}$ through which the blown air passed and heated by the solar radiation which have been absorbed by the polyethylene sheet to heat up the back surface of the stepped basin of the solar still improving the desalination process inside the still. They deduced that, compared with the conventional still the modified stepped still productivity was increased by $85 \%$, the system efficiency was reached about $59.0 \%$ with a daily 
production of $5.400 \mathrm{l} / \mathrm{m}^{2} /$ day, while, the calculated maximum theoretical productivity was $9.152 \mathrm{l} / \mathrm{m}^{2} /$ day.

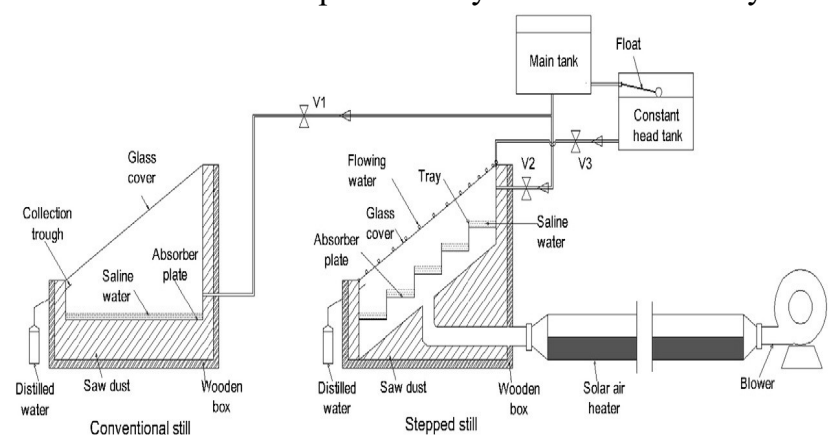

Fig.8 Active stepped solar still with solar air heater of

[13].

Salah Abdallah [14] enhanced the performance of stepped solar still equipped with PV (photovoltaic) heating coil compared with conventional still, all installed in Amman, Jordan. Their proposed stepped still consisted of three identical rectangular chambers of 0.2 $\mathrm{m}$ wide, $0.28 \mathrm{~m}$ long and $0.41 \mathrm{~m}$ height, each chamber contained a single $24 \mathrm{~V}$ heating coil powered with 30.2 $\mathrm{V}$ and 8.11 A PV module, the three heaters were connected in parallel. The proposed active stepped solar desalination system results were inferred that, the amount of produced desalinated water could be as high as $5.985 \mathrm{1} / \mathrm{m}^{2} /$ day with about $10.231 \mathrm{l} / \mathrm{m}^{2} /$ day of maximum theoretical productivity.

Moreover, Mehdiabadi et al. [15] analyzed the performance of simple shape stepped still equipped with $\mathrm{PV} /$ thermal system which provided the still with recirculated preheated saline water to increase the system productivity, the system installed in Zahedan, Iran. In their proposed system, the saline water was fed initially by recirculating pump to PV module to regulate the PV module temperature and to be preheated, then the saline water flowed to the stepped still to be desalinated. Their outcomes indicated that, for $0.03 \mathrm{l} / \mathrm{min}$ saline water flow rate the daily production was $5.710 \mathrm{l} / \mathrm{m}^{2} /$ day at $43.2 \%$ production efficiency, while the calculated maximum theoretical productivity was $13.211 \mathrm{l} / \mathrm{m}^{2} /$ day. While, Sadineni et al. [16] investigated theoretically and experimentally the effectiveness of inclined stepped solar still for water purification using continuous recirculation pump, their system was installed in Las Vegas, USA. Their system was produced up to 6.300 $1 / \mathrm{m}^{2} /$ day with a production efficiency of $61.3 \%$, while the calculated maximum theoretical productivity was $10.277 \mathrm{l} / \mathrm{m}^{2} /$ day. On the other hand, Abdallah et al. [17] evaluated the performance of simple design stepped still coupled with sun tracking mechanism in Amman, Jordan. Comparing the experimental outputs of the stepped still and the conventional one they argued that, the coupled stepped still with tracking mechanism gave about $180 \%$ increase in production higher than that for the conventional one. Furthermore, the daily desalinated water production was reached up to $5.684 \mathrm{1} / \mathrm{m}^{2} /$ day with maximum theoretical productivity of $9.500 \mathrm{l} / \mathrm{m}^{2} /$ day. Another simple shape stepped still enhancement technique was developed by Awad and El-Agous [18] using humidification / dehumidification unit coupled with the stepped still in Mansoura, Egypt. It could be noticed from Figure 9 that saline water was preheated by two electric heaters fixed in the elevated saline water tank, thereafter it entered the stepped solar still from its upper side in accordance with the blown humidification air from its lower side. There were two vessels for collecting the desalinated water installed at the outlet of steeped still collection trough and at the outlet of the dehumidifier. Their results showed that, using humidification / dehumidification unit increased the still hourly productivity and hourly efficiency by $57 \%$ and $42 \%$, respectively. Subsequently, the maximum obtained daily productivity reached about $5.500 \mathrm{l} / \mathrm{m}^{2} /$ day at an efficiency of $42.9 \%$, while, the calculated maximum theoretical productivity of their system is 12.830 $1 / \mathrm{m}^{2} /$ day.

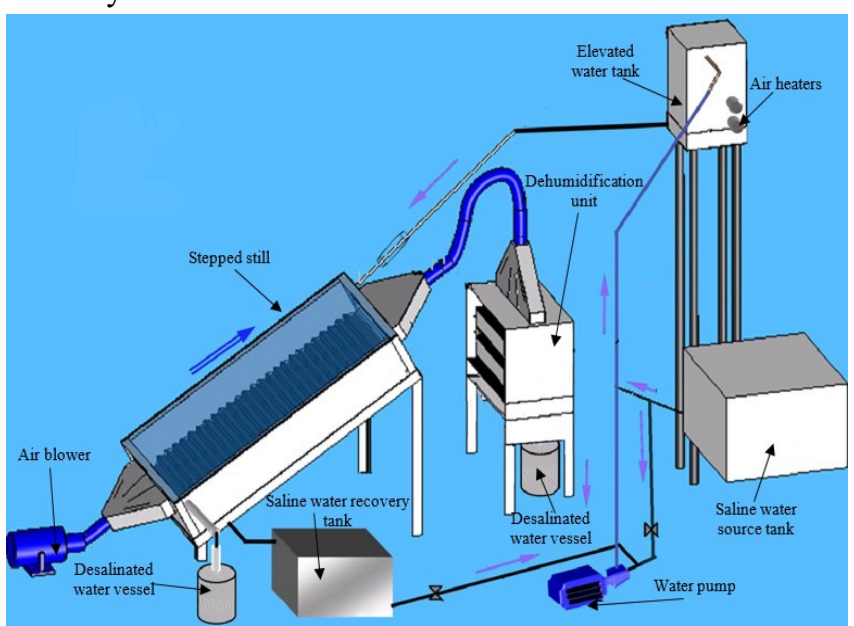

Fig.9 Schematic diagram of the stepped solar still with humidification / dehumidification unit of [18].

3.2. Stepped stills with absorber plate and glass cover modifications

The modifications based on changing absorber plate materials and shape and glass cover conditions are discussed in this section. 
3.2.1. Passive stepped solar stills under absorber plate and glass cover modifications

Abujazar et al. $[19,20]$ studied theoretically and experimentally the effect of using copper absorber and step basin trays to improve the performance of stepped solar still installed in the wet tropical climate of Bangi, Malaysia. As indicated in their system in Figure 10, the stepped type still consisted of inclined copper absorber basin with copper trays attached to the basin, each tray was worked as saline water step trough. Their system produced about $4.383 \mathrm{1} / \mathrm{m}^{2} /$ day freshwater at approximately $39.5 \%$ efficiency and the theoretical productivity of their system was about $11.096 \mathrm{l} / \mathrm{m}^{2} /$ day.

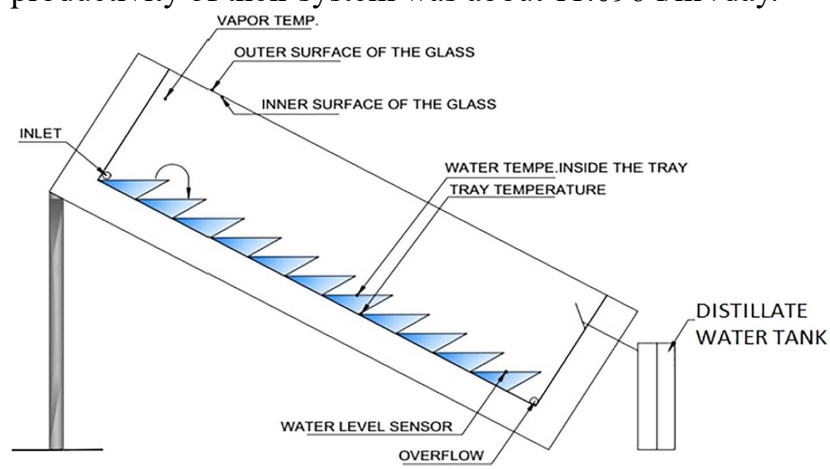

Fig.10 Schematic of the stepped solar still of $[19,20]$.

Moreover, Gawande and Bhuyar [21] analyzed experimentally the performance of stepped solar still with flat, convex and concave basin absorbers under the climate of Buldana, India. According to their outcomes, at the same seawater depth and glass cover thickness of $5 \mathrm{~mm}$ and $4 \mathrm{~mm}$, respectively, the flat basin shape gave the lowest productivity of about $1.0601 / \mathrm{m}^{2} /$ day and the concave one gave about $1.370 \mathrm{1} / \mathrm{m}^{2} /$ day of fresh water, while the convex shape basin gave the highest productivity of about $1.660 \mathrm{1} / \mathrm{m}^{2} /$ day with a theoretical productivity of $4.198 \mathrm{1} / \mathrm{m}^{2} /$ day. Furthermore, Hansen and Murugavel [22] enhanced the performance of stepped solar still and comparing the use of fin shaped and grooved absorbers with respect to conventional absorber at the same climatic conditions of Tamil Nadu, India. They recommended the use of fin shaped absorber due to its high freshwater productivity of $5.210 \mathrm{1} / \mathrm{m}^{2} /$ day at $46.9 \%$ efficiency and approximately $11.109 \mathrm{l} / \mathrm{m}^{2} /$ day of calculated theoretical productivity.

Changing the stepped solar still glass cover thickness to enhance the productivity was studied experimentally by Gawande and Bhuyar [23]. They were used two identical stepped solar stills with different glass cover thickness, one still with $3.5 \mathrm{~mm}$ and the other with $4 \mathrm{~mm}$ glass cover thickness, which were installed and tested at the same time and environmental conditions of Buldana, India. They concluded that, the bigger the glass cover thickness, the lower the desalination productivity, as the still with $4 \mathrm{~mm}$ glass cover thickness gave 1.060 $1 / \mathrm{m}^{2} /$ day of fresh water, while the other still of $3.5 \mathrm{~mm}$ glass cover thickness gave about $1.3901 / \mathrm{m}^{2} /$ day of freshwater at an efficiency of approximately $28.1 \%$. Moreover, as the glass cover thickness decreased as the total cost and payback period decreased from 823 days for the $4 \mathrm{~mm}$ cover to 628 days for the $3.5 \mathrm{~mm}$ cover. While, the calculated maximum theoretical productivity was $4.947 \mathrm{l} / \mathrm{m}^{2} /$ day.

\subsubsection{Active stepped solar stills with absorber} plate and glass cover modifications

El-samadony and Kabeel [24] estimated theoretically the effect of air wind speed and film cooling inlet temperature, flow rate and thickness in stepped solar still modified with glass cover water film cooling shown in Figure 11. Their system gave a promising data as the system daily productivity was high as $5.580 \mathrm{1} / \mathrm{m}^{2} /$ day at the optimum values of the studied parameters which should be from $2.5 \times 10^{-4} \mathrm{~m}$ to $5.5 \mathrm{x}$ $10^{-4} \mathrm{~m}$ and from $4 \times 10^{-5} \mathrm{~m}^{3} / \mathrm{s}$ to $8.5 \times 10^{-5} \mathrm{~m}^{3} / \mathrm{s}$ for cooling film thickness and flow rate, respectively, while the glass cover length should be ranged between 2 and $2.8 \mathrm{~m}$.

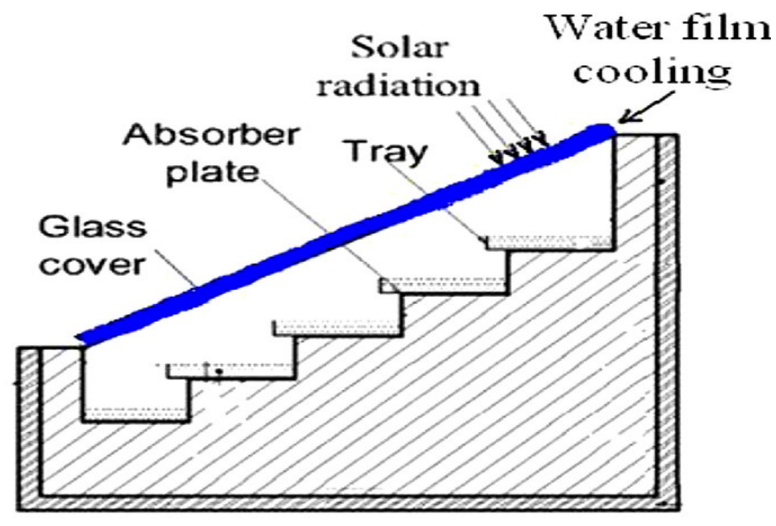

Fig.11 Active stepped solar still with glass cover film cooling of [24].

On the other hand, S. A. El-Agous [25] investigated experimentally the effect of installing cotton black absorber in stepped solar still equipped with seawater recirculation pump under the climatic conditions of 
Tanta, Egypt. Their modified still produced higher productivity of $61 \%$ than that for the conventional still of $42 \%$, furthermore, its efficiency was about $20 \%$ higher than the efficiency of the conventional one at an optimum seawater flow rate of $1 \mathrm{l} / \mathrm{min}$. While, the freshwater productivity of the modified still was reached about $6.126 \mathrm{1} / \mathrm{m}^{2} /$ day with a maximum theoretical productivity of $10.280 \mathrm{l} / \mathrm{m}^{2} /$ day. Montazeri et al. [26] as well enhanced the productivity of stepped solar still using 12 steps with $135^{\circ}$ sloping absorber plate with continuous seawater flow under the same environmental conditions of Tehran, Iran. The developed still of [26] increased the desalinated water production to be reached up to $5.190 \mathrm{l} / \mathrm{m}^{2} /$ day of freshwater under a daily desalination efficiency of $49.2 \%$, while the maximum theoretical productivity was $10.120 \mathrm{l} / \mathrm{m}^{2} /$ day.

\subsection{Stepped solar stills' basin additions improvements}

Omara et al. [27] enhanced the productivity of stepped solar still equipped with internal and external reflectors. As shown in Figure 12, the modified still of [27] was compared with conventional still at the same condition of Kafrelsheikh, Egypt, they installed both the internal and the external reflectors to increase the tendency of incoming solar radiation to the stepped still absorber surfaces which intern increase the rate of seawater evaporation and freshwater production. As a conclusion, they inferred that the developed system produced about $125 \%$ increase in productivity compared with the conventional one. Also it produced a desalinated water quantity of $8.100 \mathrm{1} / \mathrm{m}^{2} /$ day with a theoretical desalinated water production of 13.257 $1 / \mathrm{m}^{2} /$ day.

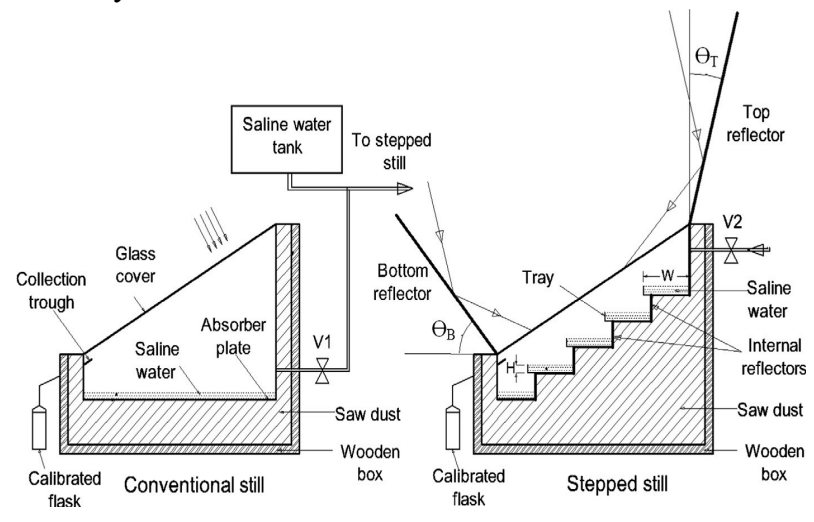

Fig.12 Passive modified stepped solar still of [27].

Improving the stepped solar still productivity by adding different heat storage materials on the absorber surface was studied experimentally by Gawande and Bhuyar [28] in Buldana, India. The enhanced stepped stills of [28] shown in Figure 13, were equipped one with square sponges and the other with circular fins, both were compared with simple stepped solar still of [10]. Both the modified systems indicated that, the productivity was increased by about $25.5 \%$ and $33.6 \%$ for stepped stills with fins and sponges respectively, compared with the simple stepped one. Furthermore, the production of freshwater for both the finned and sponge equipped stills were reached $1.330 \quad 1 / \mathrm{m}^{2} /$ day and $1.410 \quad 1 / \mathrm{m}^{2} /$ day respectively, with a theoretical desalinated water productivity of $4.198 \mathrm{l} / \mathrm{m}^{2} /$ day.

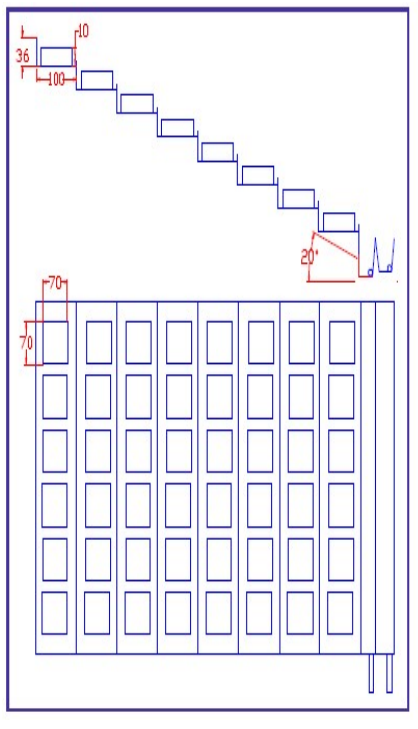

(a) Square sponges

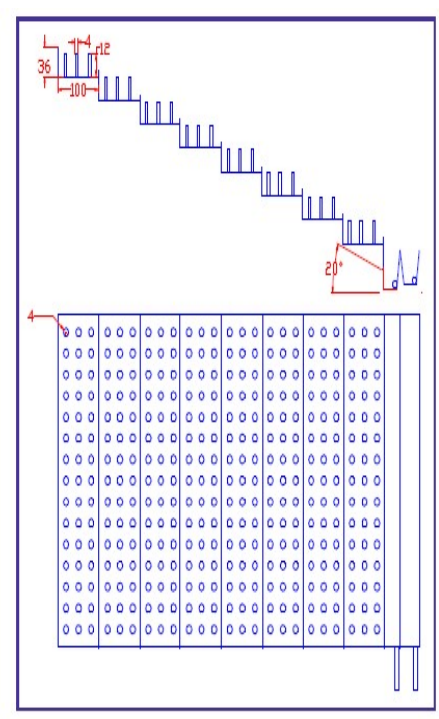

(b) Circular fins
Fig.13 Schematic of the modified stepped solar still of [28].

On the other hand, Kulkarni et al. [29] evaluated experimentally the performance of enhanced stepped solar still equipped with paraffin wax as heat storage and phase change material (PCM) and the system was installed in Maharashtra, India. While PCM temperature increased and its phase change from solid phase to liquid or even vapor phase occurred the energy was stored. On the other hand, PCM released the stored heat back to the surrounding seawater in the stepped basin during its solidification or reforming its initial shape. Their results showed that, the obtained daily productivity reached $0.975 \mathrm{l} / \mathrm{m}^{2} /$ day, while, the calculated maximum theoretical productivity of their system was 3.920 $1 / \mathrm{m}^{2} /$ day. Furthermore, Dashtban and Tabrizi $[30,31]$ in 
Zahedan, Iran, investigated theoretically and experimentally the effect of integrating stepped solar still with PCM of paraffin wax on the desalinated water production and the daily efficiency. Their modified system shown in Figure 14, produced potable water as high as $7.0001 / \mathrm{m}^{2} /$ day at an efficiency of $64.0 \%$, while, the calculated maximum theoretical productivity was $10.940 \mathrm{l} / \mathrm{m}^{2} /$ day.

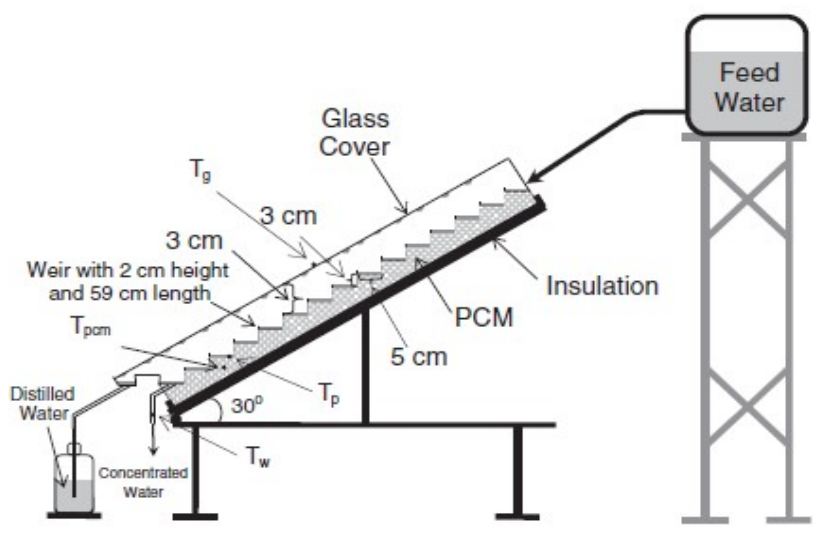

Fig.14 Schematic diagram of the stepped solar still with PCM of [30].

Another types of PCM of pebbles and rocks were used to enhance the stepped still productivity by Alaudeen et al. [32], their system which installed at Tamil Nadu, India, produced $1.7451 / \mathrm{m}^{2} /$ day of desalinated water with a daily efficiency of $16.0 \%$, while, the calculated theoretical productivity was $10.906 \mathrm{l} / \mathrm{m}^{2} /$ day. Otherwise, Sathyamurthy et al. [33] evaluated the effect of using nanoparticles in nanofluid composed of different concentration of $\mathrm{TiO}_{2}$ and $\mathrm{MgO}$ in the basin of stepped solar still installed at Chennai, India. They mentioned that comparing with conventional still without nanoparticles, the use of nanofluid with $0.1 \%$ volume concentration of $\mathrm{TiO}_{2}$ improved the stepped still productivity by $33.2 \%$, while, the use of nanofluid with $0.2 \%$ volume concentration of $\mathrm{TiO}_{2}$ improved the stepped still productivity by $41.5 \%$. On the other hand, the use of nanofluid with $0.1 \%$ and $0.2 \%$ volume concentrations of $\mathrm{MgO}$ improved the stepped still productivity by $51.7 \%$ and $61.9 \%$, respectively. Moreover, their enhanced system produced its maximum freshwater production of $4.500 \mathrm{l} / \mathrm{m}^{2} /$ day at an efficiency of $36.6 \%$ with using $0.2 \%$ volume concentrations of $\mathrm{MgO}$ nanofluid, while, the theoretical production was about $12.290 \mathrm{1} / \mathrm{m}^{2} /$ day. However, Kumar et al. [34] studied the effect of integrating stepped solar still with different wick materials as sponge cubes, wick with coconut coir, wick with cotton and plain wick. Their developed system produced its maximum freshwater quantity of $4.650 \mathrm{l} / \mathrm{m}^{2} /$ day at still efficiency of $48.0 \%$ when using compound sponges and wick with coconut coir.

To some all up, the available stepped solar stills published work which were related to their enhancement techniques and the obtained data of their desalinated water production, daily efficiency and the calculated theoretical production were presented and discussed, while, summarizing the aforementioned main findings in the following table (1).

Table 1. Comparison between stepped stills' improvement techniques findings.

\begin{tabular}{|c|c|c|c|c|c|}
\hline 音 & 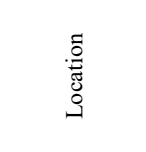 & 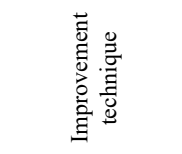 & 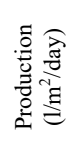 & 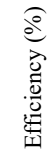 & 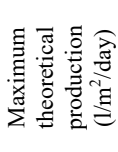 \\
\hline $\begin{array}{l}\text { Kabeel } \\
\text { et al. [7] }\end{array}$ & $\begin{array}{l}\text { Kafrelsheikh, } \\
\text { Egypt }\end{array}$ & $\begin{array}{lr}\text { Simple } & \text { shape } \\
\text { equipped } & \text { with } \\
\text { solar collector }\end{array}$ & 6.080 & 53.0 & 9.129 \\
\hline $\begin{array}{l}\text { Velmurugan } \\
\text { et al. [8] }\end{array}$ & $\begin{array}{l}\text { Madurai, } \\
\text { India }\end{array}$ & $\begin{array}{l}\text { Simple shape } \\
\text { equipped with } \\
\text { solar bond and } \\
\text { conventional } \\
\text { still }\end{array}$ & 6.120 & 59.0 & 10.368 \\
\hline $\begin{array}{l}\text { Pillai } \\
\text { et al. [9] }\end{array}$ & $\begin{array}{l}\text { Bangalore, } \\
\text { India }\end{array}$ & $\begin{array}{l}\text { Simple shape } \\
\text { under sealed and } \\
\text { unsealed } \\
\text { condition }\end{array}$ & 3.700 & 57.8 & 6.400 \\
\hline $\begin{array}{l}\text { Gawande and } \\
\text { Bhuyar [10] }\end{array}$ & $\begin{array}{l}\text { Buldana, } \\
\text { India }\end{array}$ & Simple shape & 1.200 & 28.5 & 4.210 \\
\hline $\begin{array}{l}\text { Gawande } \\
\text { et al. [11] }\end{array}$ & $\begin{array}{l}\text { Buldana, } \\
\text { India }\end{array}$ & $\begin{array}{l}\text { Simple shape } \\
\text { under changing } \\
\text { seawater depth }\end{array}$ & 1.440 & 34.3 & 4.198 \\
\hline $\begin{array}{l}\text { Islam } \\
\text { et al. [12] }\end{array}$ & $\begin{array}{l}\text { Khulna, } \\
\text { Bangladesh }\end{array}$ & Simple shape & 3.970 & 41.9 & 9.469 \\
\hline $\begin{array}{ll}\text { A. } & \text { S. } \\
\text { Abdullah } \\
{[13]}\end{array}$ & $\begin{array}{l}\text { Tanta, } \\
\text { Egypt }\end{array}$ & $\begin{array}{lr}\text { Simple } & \text { shape } \\
\text { equipped } & \text { with } \\
\text { solar air heater }\end{array}$ & 5.400 & 59.0 & 9.152 \\
\hline $\begin{array}{l}\text { Salah } \\
\text { Abdallah [14] }\end{array}$ & $\begin{array}{l}\text { Amman, } \\
\text { Jordan }\end{array}$ & $\begin{array}{lr}\text { Simple shape } \\
\text { equipped with } \\
\text { PV heating coil }\end{array}$ & 5.985 & 58.5 & 10.231 \\
\hline $\begin{array}{l}\text { Mehdiabadi } \\
\text { et al. [15] }\end{array}$ & $\begin{array}{l}\text { Zahedan, } \\
\text { Iran }\end{array}$ & $\begin{array}{l}\text { Simple shape } \\
\text { equipped with } \\
\text { PV heater and } \\
\text { recirculating } \\
\text { pump }\end{array}$ & 5.710 & 43.2 & 13.211 \\
\hline $\begin{array}{l}\text { Sadineni } \\
\text { et al. [16] }\end{array}$ & $\begin{array}{l}\text { Las Vegas, } \\
\text { USA }\end{array}$ & $\begin{array}{l}\text { Simple shape } \\
\text { equipped } \\
\text { recirculating } \\
\text { pump }\end{array}$ & 6.300 & 61.3 & 10.277 \\
\hline $\begin{array}{l}\text { Abdallah } \\
\text { et al. [17] }\end{array}$ & $\begin{array}{l}\text { Amman, } \\
\text { Jordan }\end{array}$ & $\begin{array}{lr}\text { Simple } & \text { shape } \\
\text { equipped } & \text { with } \\
\text { sun tracking } \\
\text { system }\end{array}$ & 5.684 & 59.8 & 9.500 \\
\hline $\begin{array}{l}\text { Awad and } \\
\text { El-Agous } \\
{[18]}\end{array}$ & $\begin{array}{l}\text { Mansoura, } \\
\text { Egypt }\end{array}$ & $\begin{array}{lr}\text { Simple } & \text { shape } \\
\text { equipped } & \text { with } \\
\text { electric heater } \\
\text { and } \\
\text { humidification / } \\
\text { dehumidification } \\
\text { unit }\end{array}$ & 5.500 & 42.9 & 12.830 \\
\hline $\begin{array}{l}\text { Abujazar } \\
\text { et al. }[19,20]\end{array}$ & $\begin{array}{l}\text { Bangi, } \\
\text { Malaysia }\end{array}$ & $\begin{array}{l}\text { Copper absorber } \\
\text { plate }\end{array}$ & 4.383 & 39.5 & 11.096 \\
\hline
\end{tabular}




\begin{tabular}{|c|c|c|c|c|c|}
\hline $\begin{array}{l}\text { Gawande and } \\
\text { Bhuyar [21] }\end{array}$ & $\begin{array}{l}\text { Buldana, } \\
\text { India }\end{array}$ & $\begin{array}{l}\text { Flat, convex and } \\
\text { concave } \\
\text { absorber surface } \\
\text { shapes }\end{array}$ & 1.660 & 39.5 & 4.198 \\
\hline $\begin{array}{l}\text { Hansen and } \\
\text { Murugavel } \\
\text { [22] }\end{array}$ & $\begin{array}{l}\text { Tamil Nadu, } \\
\text { India }\end{array}$ & $\begin{array}{l}\text { Grooved and } \\
\text { finned absorber } \\
\text { plate shapes }\end{array}$ & 5.210 & 46.9 & 11.109 \\
\hline $\begin{array}{l}\text { Gawande and } \\
\text { Bhuyar [23] }\end{array}$ & $\begin{array}{l}\text { Buldana, } \\
\text { India }\end{array}$ & $\begin{array}{l}\text { Changing glass } \\
\text { cover thickness }\end{array}$ & 1.390 & 28.1 & 4.947 \\
\hline $\begin{array}{l}\text { El-samadony } \\
\text { and Kabeel } \\
{[24]}\end{array}$ & $\begin{array}{l}\text { Tanta, } \\
\text { Egypt }\end{array}$ & \begin{tabular}{l}
\multicolumn{2}{l}{ Glass cover with } \\
water \\
cooling
\end{tabular} & 5.580 & $\begin{array}{l}\text { N. } \\
\text { A. }\end{array}$ & N. A. \\
\hline $\begin{array}{ll}\text { S. } & \text { A. } \\
\text { El-Agous } \\
{[25]}\end{array}$ & $\begin{array}{l}\text { Tanta, } \\
\text { Egypt }\end{array}$ & $\begin{array}{lr}\text { Cotton black } \\
\text { absorber with } \\
\text { continuous } \\
\text { seawater flow }\end{array}$ & 6.126 & 61.0 & 10.280 \\
\hline $\begin{array}{l}\text { Montazeri } \\
\text { et al. [26] }\end{array}$ & $\begin{array}{l}\text { Tehran, } \\
\text { Iran }\end{array}$ & $\begin{array}{l}\text { Sloping absorber } \\
\text { plate with } \\
\text { continuous } \\
\text { seawater flow }\end{array}$ & 5.190 & 49.2 & 10.120 \\
\hline $\begin{array}{l}\text { Omara } \\
\text { et al. [27] }\end{array}$ & $\begin{array}{l}\text { Kafrelsheikh, } \\
\text { Egypt }\end{array}$ & $\begin{array}{ll}\text { Internal and } \\
\text { external } \\
\text { reflectors }\end{array}$ & 8.100 & 61.1 & 13.257 \\
\hline $\begin{array}{l}\text { Gawande and } \\
\text { Bhuyar [28] }\end{array}$ & $\begin{array}{l}\text { Buldana, } \\
\text { India }\end{array}$ & $\begin{array}{l}\text { Square sponges } \\
\text { and circular fins } \\
\text { additions }\end{array}$ & 1.410 & 33.6 & 4.198 \\
\hline $\begin{array}{l}\text { Kulkarni } \\
\text { et al. [29] }\end{array}$ & $\begin{array}{l}\text { Maharashtra, } \\
\text { India }\end{array}$ & PCM addition & 0.975 & 24.9 & 3.920 \\
\hline $\begin{array}{l}\text { Dashtban and } \\
\text { Tabrizi [30, } \\
\text { 31] }\end{array}$ & $\begin{array}{l}\text { Zahedan, } \\
\text { Iran }\end{array}$ & $\begin{array}{l}\text { Paraffin wax as } \\
\text { PCM addition }\end{array}$ & 7.000 & 64.0 & 10.940 \\
\hline $\begin{array}{l}\text { Alaudeen } \\
\text { et al. [32] }\end{array}$ & $\begin{array}{l}\text { Tamil Nadu, } \\
\text { India }\end{array}$ & $\begin{array}{lr}\text { Rocks } & \text { and } \\
\text { pebbles } & \text { as } \\
\text { sensible heat } \\
\text { storage materials }\end{array}$ & 1.745 & 16.0 & 10.906 \\
\hline $\begin{array}{l}\text { Sathyamurthy } \\
\text { et al. [33] }\end{array}$ & $\begin{array}{l}\text { Chennai, } \\
\text { India }\end{array}$ & $\begin{array}{l}\mathrm{MgO} \text { and } \mathrm{TiO}_{2} \\
\text { as nanoparticles } \\
\text { addition }\end{array}$ & 4.500 & 36.6 & 12.290 \\
\hline $\begin{array}{l}\text { Kumar } \\
\text { et al. [34] }\end{array}$ & $\begin{array}{l}\text { Chittoor, } \\
\text { India }\end{array}$ & $\begin{array}{l}\text { Coconut coir } \\
\text { and sponge as } \\
\text { wicks }\end{array}$ & 4.650 & 48.0 & 9.687 \\
\hline
\end{tabular}

Subsequently, due to the high water demand [35] and the shortage of energy sources [36], the solar stills are acceptable facility to produce desalinated water [37]. Accordingly, using modified and efficient solar still is a substantial issue [38], especially in hot and arid regions such as Upper Egypt [39]. Therefore, using combined amendment of external reflectors, high thermal conductive fins, high absorptive basin, transparent walls and internal reflectors is extremely recommended [40].

\section{Conclusion}

Throughout the literature survey on the stepped solar stills' improvement techniques, the following conclusions can be drawn: -

- The highest productivity of $8.100 \mathrm{l} / \mathrm{m}^{2} /$ day was given by using internal and external reflectors at Kafrelsheikh, Egypt, with theoretical productivity of $13.257 \mathrm{l} / \mathrm{m}^{2} /$ day. Subsequently, there is a room to improve such still productivity with about $5.157 \mathrm{l} / \mathrm{m}^{2} /$ day adding further modification techniques.
- $\quad$ The stepped solar still is an auspicious system to be installed in hot arid and harsh regions such as Middle East to provide a considerable amount of freshwater needs.

It is clarified that the overall performance of the existing modified stepped solar still is still not satisfactory. Therefore, the stepped solar still needs further integration of new modifications. Moreover, significant progress should be implemented especially for higher productivity and cost reduction to commercialize such type of promising solar stills in hot arid and harsh regions.

\section{Author Contribution STATEMEnT}

Ahmed N. Shmroukh: Writing, Original draft preparation, Conceptualization, Methodology, Formal analysis, Data collection. Shinichi Ookawara: Reviewing, Editing, Supervision, Formal analysis.

\section{ACKNOWLEDGMENT}

The first author would like to acknowledge Ministry of Higher Education (MoHE) of Egypt for providing a scholarship to conduct this study.

\section{References}

[1] M. Kummu, J. H. A. Guillaume, H. de Moel, S. Eisner, M. Flörke, M. Porkka, S. Siebert, T. I. E. Veldkamp, P. J. Ward. The world's road to water scarcity: shortage and stress in the 20th century and pathways towards sustainability. Scientific Reports, vol. 6 (2016), 38495.

[2] Ahmed N.Shmroukh, M.Attalla, Amany Abd El-Naser Abd El-Hakim. Experimental investigation of a novel sea water desalination system using ranque-hilsch vortex tube. Applied Thermal Engineering. vol 149 (2019), pp 658-664.

[3] Ahmed Nagah Shmroukh, Ali Radwan, Abdalla Abdal-hay, Ahmed A. Serageldin, Mahmoud Nasr. New configurations for sea water desalination system using Ranque-Hilsch vortex tubes. Applied Thermal Engineering, vol 157 (2019), 113757.

[4] Nadarajah Kannan, Divagar Vakeesan. Solar energy for future world: - A review. Renewable and Sustainable Energy Reviews, vol. 62 (2016), pp 1092-1105.

[5] Ahmed N. Shmroukh. Thermal regulation of photovoltaic panel installed in Upper Egyptian conditions in Qena. Thermal Science and Engineering Progress, vol. 14 (2019), 100438.

[6] E. El-Bialy. Performance analysis for passive single slope single basin solar distiller with a floating absorber - An experimental study. Energy, vol. 68 (2014), pp 117-124. 
[7] A.E. Kabeel, A. Khalil, Z.M. Omara, M.M. Younes. Theoretical and experimental parametric study of modified stepped solar still. Desalination, vol. 289 (2012), pp 12-20.

[8] V. Velmurugan, S. Pandiarajan, P. Guruparan, L. Harihara Subramanian, C. David Prabaharan, K. Srithar. Integrated performance of stepped and single basin solar stills with mini solar pond. Desalination, vol. 249 (2009), pp 902-909

[9] Rohit Pillai, A. T. Libin, M. Mani. Study into solar-still performance under sealed and unsealed conditions. International Journal of Low-Carbon Technologies. vol. 10 (2015), pp 354-364.

[10] J.S. Gawande, L.B. Bhuyar. Effect of Climatic Parameters on the Performance of Different Designs of Stepped Type Solar Still. Current Trends in Technology and Science, vol. 2 (2012), pp 206-212.

[11] Jagannath S. Gawande, Lalit B. Bhuyar, Samir J. Deshmukh. Effect of Depth of Water on the Performance of Stepped Type Solar Still. International Journal of Energy Engineering, vol. 3 (2013), pp 137-143.

[12] Kh. Md. Shafiul Islam, Shuvo Ramo Saha, Md. Abu Jafor, Md. Abu Raihan. Water Desalination Using Basin Type Solar Still. Journal of Engineering Science, vol. 4 (2013), pp 1-9.

[13] A.S. Abdullah. Improving the performance of stepped solar still. Desalination, vol. 319 (2013), pp 60-65.

[14] Salah Abdallah. Productivity Enhancement of Solar Still with PV Powered Heating Coil and Chamber Step-Wise Basin. Journal of Ecological Engineering, vol. 19 (2018), pp 8-15.

[15] E. Hedayati-Mehdiabadi, F. Sarhaddi, F. Sobhnamayan. Energy analysis of a stepped cascade solar still connected to photovoltaic thermal collector. International Journal of Automotive and Mechanical Engineering, vol. 14 (2017), pp 4805-4825.

[16] S.B. Sadineni, R. Hurt, C.K. Halford, R.F. Boehm. Theory and experimental investigation of a weir-type inclined solar still. Energy, vol. 33 (2008), pp 71-80.

[17] Salah Abdallah, Omar Badran, Mazen M. Abu-Khader. Performance evaluation of a modified design of a single slope. Desalination, vol. 219 (2008), pp 222-230.

[18] Mostafa M. Awad, S. A. El-Agouz. Enhancement of the Performance of Stepped Solar Still Using Humidification-Dehumidification Processes. Nature and Science, vol. 11 (2013), pp 88-98.

[19] Mohammed Shadi S. Abujazar, S. Fatihah, E.R. Lotfy, A.E. Kabeel, Suraya Sharil. Performance evaluation of inclined copper-stepped solar still in a wet tropical climate. Desalination, vol. 425 (2018), pp 94-103.

[20] Mohammed Shadi S. Abujazar, S. Fatihah, A.E. Kabeel. Seawater desalination using inclined stepped solar still with copper trays in a wet tropical climate. Desalination, vol. 423 (2017), pp 141-148.

[21] Jagannath S. Gawande, Lalit B. Bhuyar. Effect of Shape of the Absorber Surface on the Performance of Stepped Type Solar Still. Energy and Power Engineering, vol. 5 (2013), pp 489-497.

[22] R. Samuel Hansen, K. Kalidasa Murugavel. Enhancement of integrated solar still using different new absorber configurations: An experimental approach. Desalination, vol. 422 (2017), pp 59-67.

[23] J.S. Gawande, L.B. Bhuyar. Effect of Glass Cover Thickness on The Performance of Stepped Type Solar Still. International Journal of Innovative Research in Technology \& Science, vol. 1 (2013), pp 19-26.

[24] Y.A.F. El-Samadony, A.E. Kabeel. Theoretical estimation of the optimum glass cover water film cooling parameters combinations of a stepped solar still. Energy, vol. 68 (2014), pp 744-750.

[25] S.A. El-Agouz. Experimental investigation of stepped solar still with continuous water circulation. Energy Conversion and Management, vol. 86 (2014), pp 186-193.

[26] Mehdi Montazeri, Ahmad Banakar, Barat Ghobadian. Enhancement of cascade solar still productivity with sloping absorber plate. Maejo International Journal of Science and Technology, vol. 11 (2017), pp 35-44.

[27] Z.M. Omara, A.E. Kabeel, M.M. Younes. Enhancing the stepped solar still performance using internal and external reflectors. Energy Conversion and Management, vol. 78 (2014), pp 876-881.

[28] J.S. Gawande. Effect of Enhancements Provided on the Performance of Stepped Type Solar Still. International Journal of Innovations in Engineering and Technology, vol. 2 (2013), pp 57-69.

[29] Hrushikesh Kulkarni, Chinmay Kute, Chirag Patel, Akshay Tavse, Prof. Lokesh R. Dhumne. Experimental Investigation and Performance Evaluation of Solar Still Using Phase Change Material. International Research Journal of Engineering and Technology, vol. 5 (2018), pp 1109-1118. [30] Mohammad Dashtban, Farshad Farshchi Tabrizi. Thermal analysis of a weir-type cascade solar still integrated with PCM storage. Desalination, vol. 279 (2011), pp 415-422.

[31] Farshad Farshchi Tabrizi, Mohammad Dashtban, Hamid Moghaddam. Experimental investigation of a weir-type cascade solar still with built-in latent heat thermal energy storage system. Desalination, vol. 260 (2010), pp 248-253.

[32] A. Alaudeen, K. Johnson, P. Ganasundar, A. Syed Abuthahir, K. Srithar. Study on stepped type basin in a solar still. Journal of King Saud University - Engineering Sciences, vol. (2014) 26, pp 176-183.

[33] Ravishankar Sathyamurthy, Abd Elnaby Kabeel, El-Sayed El-Agouz, DSilva Rufus, Hitesh Panchal, Thirugnanasambantham Arunkumar, Athikesavan Muthu Manokar, David Gnanaraj Prince Winston. Experimental investigation on the effect of $\mathrm{MgO}$ and $\mathrm{TiO}_{2}$ nanoparticles in stepped solar still. International Journal Energy Research, vol. 43 (2019), pp 3295-3305.

[34] P. Ramesh Kumar, K. Srithar, T. Rajaseenivasan, M. Vivar, M. Fuentes. Proficiency improvement study on an inclined stepped solar still with different wick materials. Journal of Desalination and Water Purification, vol. 13 (2018), pp 3-10.

[35] Nasr, M., Shmroukh, A.N. Gray-to-Green Infrastructure for Stormwater Management: An Applicable Approach in Alexandria City, Egypt. Advances in Science, Technology and Innovation, 2020, pp. 369-379.

[36] Awad M., Radwan A., Abdelrehim O., Emam M., Shmroukh A.N., Ahmed M. Performance evaluation of concentrator photovoltaic systems integrated with a new jet impingement-microchannel heat sink and heat spreader. Solar Energy, 2020, 199, pp. 852-863.

[37] Mohammed, A.H., Attalla, M., Shmroukh, A.N. Performance enhancement of single-slope solar still using phase change materials. Environmental Science and Pollution Research, 2021, 28(14), pp. 17098-17108.

[38] Shmroukh, A.N., Serageldin, A.A., Abdal-hay, A., Elreedy, A., Radwan, A. Application of new series connection scheme of vortex tubes in seawater desalination unit using new vortex generators. SN Applied Sciences, 2021, 3(2), 177.

[39] Mostafa, M., Ezzeldien, M., Attalla, M., Ghazaly N.M. Alrowaili Z.A. Hasaneen, M.F., Shmroukh, A.N. 
Comparison of different adsorption pairs based on zeotropic and azeotropic mixture refrigerants for solar adsorption ice maker. Environmental Science and Pollution Research, 2021, 28(30), pp. 41479-41491.

[40] Shmroukh, A.N., Ookawara, S. Evaluation of transparent acrylic stepped solar still equipped with internal and external reflectors and copper fins. Thermal Science and Engineering Progress, 2020, 18, 100518. 